\title{
The von Restorff effect and measures of organization in normals and retardates*
}

\author{
JOHN J. WINTERS, JR. \\ E. R. Johnstone Training and Research Center, Bordentown, New Jersey 08505 \\ and \\ LEONARD C. ATTLEE \\ Newark State College, Union, New Jersey 07083
}

\begin{abstract}
Thirty-two noninstitutionalized retardates and 32 normals of equal mental age (approximately 8 years) heard 10 orders of 10 nouns when the decibel $(\mathrm{dB})$ level of the stimuli was the same and when the $\mathrm{dB}$ level of the sixth item was higher. The von Restorff effect was demonstrated by both groups. The normals' overall recall was superior to that of the retardates' recall. Differences in recall were attributed to the normals' tendency to recall items in the same serial order more consistently. The subjective organization of lists, as measured by order of recall, differed for the normals and retardates; the normal group was more adaptable than the retarded group in adjusting their strategy to different list conditions.
\end{abstract}

The von Restorff effect is demonstrated when a heterogeneous item that is embedded within a list of homogeneous items is recalled better than when that item is presented in the same position in a list for which that item is homogeneous. Explanations for this phenomenon are several (see Wallace, 1965, for a review).

Previous investigations of the von Restorff effect with mental retardates have demonstrated that retardates exhibit this phenomenon, but to a lesser extent than do college students (Deutsch \& Sternlicht, 1967; Sternlicht \& Deutsch, 1966) or normals of the same chronological age (McManis, 1966). The effect is also manifested by retardates when multiple items are isolated (Sen, Clarke, \& Cooper, 1968). Jacobs and Foshee (1971) found that by reinforcing the retardate to attend to the unique items, overall list recall was facilitated. Their findings were interpreted in terms of increased rehearsal enhancing recall.

It should be noted that whenever list learning has been facilitated with the von Restorff phenomenon, the isolating factor was a change in chromaticity of the unique item (Wallace, 1965). Jacobs and Foshee (1971) used chromaticity and found list facilitation whether or not the isolated items were reinforced. Sen et al (1968) found list facilitation when chromatic pictures were the isolated items, though no reinforcement was given.

\footnotetext{
*The authors are grateful to Mrs. Safrony-Bell of the Avalon Public School System, Avalon, New Jersey, and to Mr. McCullough, Mr. Zaslavsky, and Dr. Zapelski of the Howell Township School System, Lakewood, New Jersey, and their respective staffs for their cooperation. We are also indebted to Mrs. Winters for recording the stimuli, Mr. Hoats for his technical assistance, and Herman $H$. Spitz for his critical reading of the manuscript. This study was supported in part by NICHD Grant HD 07329. Requests for reprints should be sent to John J. Winters, Jr., E. R. Johnstone Training and Research Center, Bordentown, New Jersey 08505.
}

McManis (1966) used chromaticity and meaningfulness as isolating factors but did not report overall learning results. Finally, Sternlicht and Deutsch (1966) embedded three-digit numbers in a list of CVC syllables, and vice versa, and elicited the von Restorff effect but had no control condition to determine whether list learning was facilitated. The available evidence, then, indicates that list learning is facilitated in retardates when chromaticity is the isolating factor. It is, therefore, possible that retardates' overall improved recall may be due to the nature of the isolating factor (Wallace, 1965).

When retardates and normals of equal mental age are compared on verbal learning tasks, it is often found that the normals' recall is superior to retardates' recall (Goulet, 1968). This superiority has been attributed to group differences in such subjective control processes as rehearsal (Ellis, 1970), verbal mediation (Milgram, 1968), and organization of the stimuli (Spitz, 1966).

The type of subjective organization (SO) can and does vary. Winters, Gerjuoy, Crown, and Gorrell (1967) reported that, when retardates and normals of equal mental age and equal chronological age viewed a series of simultaneously exposed letters presented tachisticopically, the normal Ss, who were more accurate in recognition, were also more consistent in their order of recall. Within the retarded group, those Ss who were more consistent in their order of recall of the test items were also more accurate. If consistency of response aids recall with simultaneously presented stimuli, it might also facilitate recall of sequentially presented stimuli in a free recall task.

Though Shuell (1969) has pointed out the tenuous relationship between free recall and measures of internal organization, Sitko (1970) found that, when mental retardates and normals of equal chronological age were compared, the normals' recall and SO were related, whereas no relationahip occurred for the retardates. On 
the other hand, Leicht and Johnson (1970) found a significant positive relationship between overall recall and SO in retardates though they were not highly related. A concern of the present study is to determine whether differing organizational strategies are related to recall in retardates and normals of equal mental age in a free recall paradigm when a homogeneous and a von Restorff list are presented.

Thus, the two main purposes of this study are (1) to determine whether list facilitation will occur with two young equal mental age groups when audition, i.e., decibel $(\mathrm{dB})$ level, is used as the isolating factor rather than chromaticity and (2) to investigate measures of organization and their relationship to recall in these two groups.

\section{METHOD}

\section{Subjects}

Thirty-two normals $(\overline{\mathrm{C}} \overline{\mathrm{A}}=7.93$ years, $\mathrm{SD}=.45$ years; $\overline{\mathrm{Q}}=100.19, \mathrm{SD}=10.70 ; \overline{\mathrm{MA}}=7.93$ years, $\mathrm{SD}=.75$ years $)$ and 32 noninstitutionalized retardates $(\overline{\mathrm{CA}}=11.82$ years, $\mathrm{SD}=2.14$ years, $\overline{\mathrm{IQ}}=66.59, \mathrm{SD}=5.47 ; \overline{\mathrm{MA}}=7.83$ years, $\mathrm{SD}=1.36$ years) were tested. Intelligence test scores for the normal Ss were from group administered tests and for the retardates were from individually administered tests. The retardates were free of gross motor defects and were classified as cultural-familial. Members of both groups were from the middle- and low-SES levels.

\section{Stimuli and Procedure}

The stimuli consisted of two lists of 10 words each and a training list of four words. All words had a Thorndike-Lorge rating of A or AA. Four different orders of the training list were recorded at a 2 -sec rate with a 10 -sec intertrial interval for free recall, and 10 different orders of each of the two lists were recorded at a 2 -sec rate with a 30 -sec intertrial interval for free recall. Pilot work indicated that after $30 \mathrm{sec}$ of recall few, if any, additional words were recalled by either group.

The training lists and two control test lists were transcribed from the master tapes so that all words were homogeneous as to $\mathrm{dB}$ level. The two experimental test lists were also transcribed from the master tapes, with a different word (the sixth word) in each trial amplified. The isolation of a different stimulus on each trial is consistent with Jacobs and Foshee's (1971) and McManis's (1966) paradigm. The training lists, control lists, and control items in the experimental list had a $\overline{\mathrm{dB}}$ of 77.34 , $\mathrm{SD}=3.18$; the isolated items had a $\overline{\mathrm{dB}}$ of $90.60, \mathrm{SD}=3.02 .^{1}$

Each $S$ received the four training trials to demonstrate that, when the signal ("click") was heard at the end of each presentation, he was to recall the list until he heard another signal ("beep"), at which time he was to listen to the next presentation of the list. The S's task was to free recall orally as many words as possible between the "click" and the "beep."

All Ss were tested in two sessions, receiving 10 trials of either the experimental or control condition in each session. The experimental and control conditions were presented on successive days in counterbalanced order with a different list in each condition. Each session lasted between 10 and $15 \mathrm{~min}$. Half of each group in each condition were males. There were four conditions: List 1 experimental, List 1 control, List 2 experimental, List 2 control. Experimental conditions, list, and sex were orthogonally balanced.

\section{RESULTS}

\section{Overall Learning and von Restorff Effect}

The scores analyzed were the number of items recalled at each serial position in each condition. Preliminary analyses of test conditions indicated that no list or sex differences occurred, and these variables were dropped from further analyses.

In the training and test conditions, no $S$ recalled while a list was being presented and all Ss started free recall immediately after the "click." During training, the two groups did not differ in total recall or in the number of items recalled on any of the four trials.

Cochran's test for homogeneity of variance of the test data among groups, experimental conditions, and order of conditions revealed no significant differences among cell variances $[C(8,15)=.16]$.

A 2 by 2 by 2 by 10 ANOVA (groups by order of conditions by conditions by serial position) on the test data revealed that three main effects, three first-order interactions, three second-order interactions, and the third-order interaction were significant.

The results indicate that (1) recall by the normals was superior to recall by the retardates $[F(1,60)=27.49$, $p<.01]$; (2) recall was superior when the control condition was presented first $[F(1,60)=5.44, p<.05]$; (3) recall of items differed depending upon their position in the list $[F(9,540)=284.18, p<.01] ;(4)$ the two groups differed more at Serial Positions 3 , 4, and 8 than at other points on the lists and differed not at all at Serial Position $10[F(9,540)=4.44, p<.01] ;(5)$ when the control list was given first, more items were recalled at all positions except the fifth and seventh $[F(9,540)=2.67, p<.01]$; (6) the items in the sixth position of the experimental list were recalled better than items in the same position of the control list $[F(9,540)=89.59, p<.01] ;(7)$ the normals did not differ in recall whether the control list was presented first or second, and the retardates did not differ in recall whether the experimental list was presented first or second, but the normals' performance was superior when the experimental list was given second as compared to when it was given first, while the retardates' performance was superior when the control list was given first as compared to when it was given second $[\mathrm{F}(1,540)=8.12, \mathrm{p}<.01] ;(8)$ normals' performance was better than retardates' performance in each serial position within each condition, except for the sixth and tenth positions of the experimental lists (see Fig. 1) $[F(9,540)=2.00, p<.05] ;(9)$ when the control list was given first, recall was superior in all positions as compared to when it was given second; when the experimental list was given first, recall was inferior as compared to when it was given second, except for the 


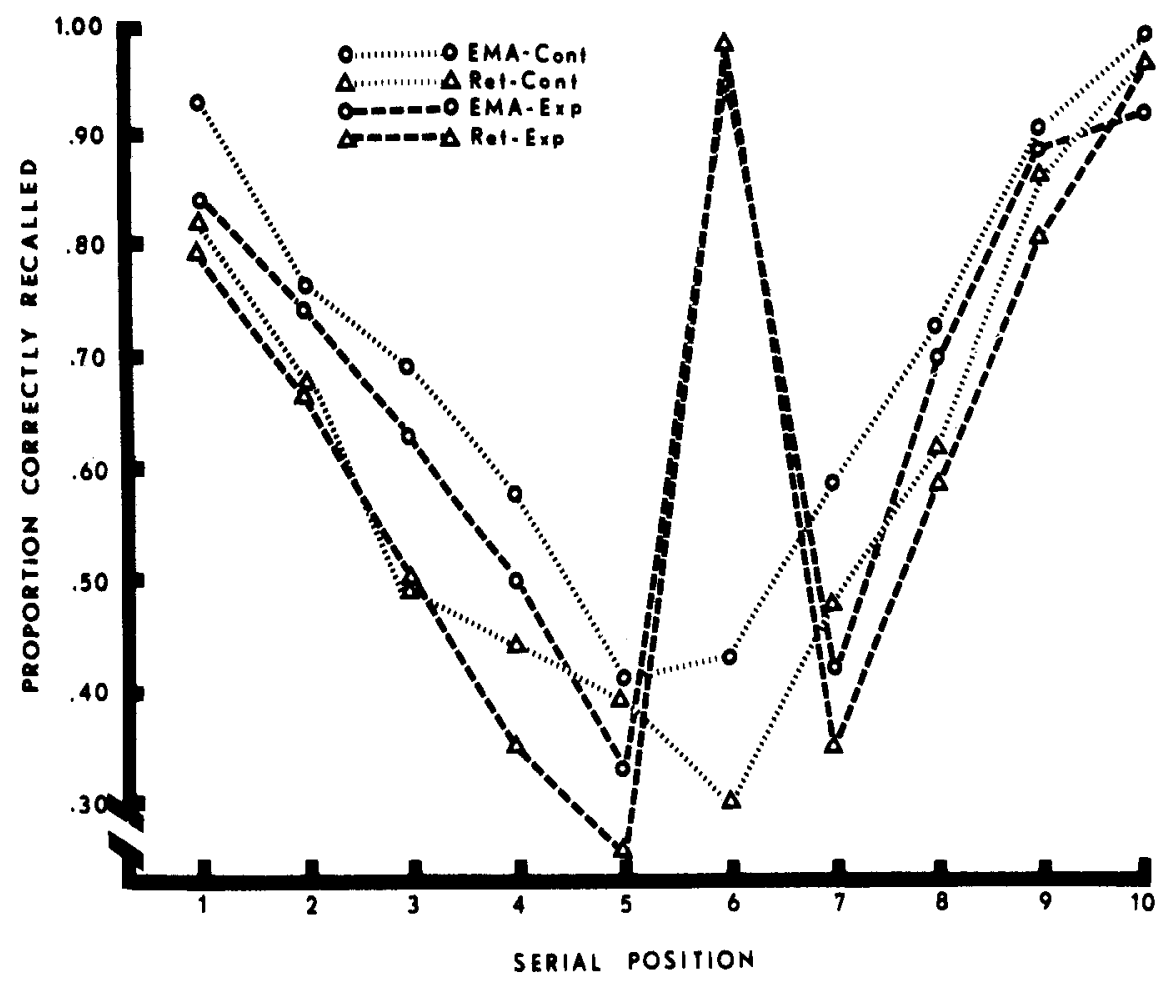

Fig. 1. Proportion of items correctly recalled by retardates (Ret) and EMA normals in the control (Cont) and experimental (Exp) conditions of each serial position with order of presentation coinciding with serial position ( 1 is first word presented, 10 is last word presented).

fifth and seventh positions $[F(9,540)=5.11, p<.01]$; (10) the third-order interaction was also significant $[F(9,540)=5.91, p<.01]$, but a description would be too complex and of little substantive importance.

The proportion of items correctly recalled by both groups in each condition at each serial position is depicted in Fig. 1. The findings that groups and serial position differed, while conditions did not, were not unexpected, nor was the superior performance of the normals on the primacy portion of the list and the superior performance by both groups on the isolated items. However, the Groups by Conditions by Serial Position interaction was not anticipated, nor was the significant main effect of order and the interactions due to this main effect. Apparently, performance was more deleteriously effected when the experimental list was presented first, due to the disruptive nature of the list, but the normals adapted better in the second session than did the retardates.

\section{Measures of Organization}

The purpose of the following analyses is to determine whether measures of organization can account for differences in recall within and between groups of Ss, conditions, and order of presentation. Since the order of presentation influenced free recall, this was included as a variable.

Three separate 2 by 2 by 2 analyses of variance were performed (groups by order of presentation by conditions). In the first analysis, Bousfield, Puff, and Cowan's (1964) measure of intertrial repetitions (ITR) was used as a measure of organization. Each S's ITR in each condition was the dependent measure. In a second analysis, Bousfield and Bousfield's (1966) updated measure of ITR was used as the dependent measure in order to determine whether these two different measures of organization produced different results. Both analyses revealed that the Order by Conditions interaction was significant $(p<.01)$. No other main effects or interactions were significant, nor were there any significant correlations between ITR and recall for either group, condition, order, or analysis.

Tulving's (1962) measure of SO, which is based on information theory, was used as another measure of organization. Each S's SO was determined in each condition, and a 2 by 2 by 2 analysis was performed using the same factors as above. This measure revealed no significant effects or interactions but did produce a significant positive correlation when the normals received the control lists first $[\mathrm{r}(15)=.59, \mathrm{p}<.05]$. Significant negative correlations occurred when the retardates received the control list second $[\mathrm{r}(15)=-.64$, $\mathrm{p}<.01]$, the normals the experimental list first $[\mathrm{r}(15)=-.53, \mathrm{p}<.05]$, and the experimental list regardless of order $[\mathrm{r}(31)=-.55, \mathrm{p}<.01]$. These negative relationships would indicate that $S s$ who recalled more were less consistent in their SO. This might be expected if there was a tendency to organize items in a manner other than one based on verbal associations.

Another approach to measuring organization of recall, in addition to SO or ITR, would be to determine whether the sequences in which items were presented 
influenced order of recall. That is, whether Ss, instead of reorganizing stimuli into subjectively meaningful units, recalled them as a function of the order in which they were presented on each trial by $\mathrm{E}$.

Consistency of serial recall (CS), as influenced by the serial order of presentation, can be determined by calculating the variance of order of recall for each serial position by each $S$. This was computed from a 10 by 10 matrix for each $S$, in which the order the items were presented on each trial is represented by the rows and the trials are represented by the columns. The order in which items were recalled was noted. The variance of each row for each $S$ indicates his position variance $\left(\mathrm{Ps}^{2}\right)$. The smaller an S's $\mathrm{Ps}^{2}$, the greater the degree of consistency. Since total amount recalled influences $\mathrm{Ps}^{2}$ $(\mathrm{r}=.54$ and .48 for the normals and retardates, respectively), the variance of each trial $\left(\mathrm{Ts}^{2}\right)$ can be used to correct for this bias. Thus, the formula $C S=\Sigma P s^{2}-\Sigma T s^{2}$ ) was used for each $S$ in order to determine his consistency of recall. A log transformation of each S's CS attenuated the positively skewed scores.

Analyses of variance on the transformed data indicated that the normals were marginally more consistent than the retardates in order of recall $[F(1,60)=3.95, p<.06]$; the significant Order by Conditions interaction $[F(1,60)=7.21, p<.01]$ revealed that there was more consistency in serial order of recall when the control condition was presented first; the significant Groups by Order by Conditions interaction $[F(1,60)=5.92, p<.05]$ was a result of less consistency by the retardates when the homogeneous condition was presented first. No other main effects or interactions were significant.

Correlations between CS and recall revealed that, when the normals received the control condition first $[\mathrm{r}(15)=-.57, \mathrm{p}<.02]$, second $[\mathrm{r}(15)=-.54, \mathrm{p}<.05]$, and in both orders $[\mathrm{r}(31)=-.52, \mathrm{p}<.01]$, consistency in serial order of recall was related to overall recall (the lower the CS, the less the variance and the higher the recall). Significant relationships did not exist for the normals in the experimental condition, nor for the retardates in either the control or experimental condition. Overall, the normal group demonstrated a significant relationship $[\mathrm{r}(31)=-.42, \mathrm{p}<.02]$, whereas the retardates did not. Thus, consistency of serial order of recall, when items are presented sequentially, apparently is related to amount of recall in the normal group.

Though CS was not significantly related to recall in the experimental condition for either group of Ss, the difference between the correlations of CS and recall for the two groups $(Z=1.68)$ does indicate that there was a somewhat higher relationship between CS and recall for the normals. The lack of a significant difference between the two groups or significant relationship between CS and recall in the experimental list might be attributable to the disruptive nature of the isolated item. This is suggested by the slightly lower correlation between the average order in which items were recalled in the control and experimental lists by normals (.47) as compared to retardates (.62). It is supported by the findings that when the control list was presented to the retardates the last item was recalled first $62 \%$ of the time, while the isolated item of the experimental list was recalled first $61 \%$ of the time. When the normals received the control list, the last item was recalled first 53\% of the time, whereas the isolated item of the experimental list was recalled first more often, $69 \%$ of the time $[\mathrm{t}(31)=5.10$, $\mathrm{p}<.01]$. Also, retardates recalled the last item in the control list first more often than did the normals [ $t(62)=2.58, \mathrm{p}<.01]$, while the normals recalled the isolated item of the experimental list first more often than did the retardates $[\mathrm{t}(62)=2.94, \mathrm{p}<.01]$.

Thus, whether the control or experimental list was given, the retardates started recall with the most salient item, either the most recent item or the isolated item, treating both conditions similarly in average order of recall $[\mathrm{r}(9)=.62, \mathrm{p}<.05]$. The normals, on the other hand, were not as inclined to start with the most recent item in the control conditions but were more consistent in their order of recall. When the experimental list was presented, they were more inclined to be effected by the isolated item, recalling it first more often than did the retardates and more often than they did the most recent item in the control conditions. They did not treat both conditions similarly in average order of recall $[\mathrm{r}(9)=.47$, n.s.] . Apparently, the homogeneous condition allowed consistent recall for the normals but the experimental condition did not.

\section{DISCUSSION}

Contrary to Jacobs and Foshee's (1971) findings, no list facilitation occurred in the experimental condition for the retardates. Neither did it occur for the normals. It should be noted that, though their retarded Ss demonstrated list facilitation when all of the items that were isolated were reinforced, when the isolated items were not reinforced performance in the experimental conditions was still superior to performance in the control condition. Whether the different results in list facilitation between their study and this one were due to the nature of the isolated items or absence of reinforcement is undetermined in view of the unique results obtained when chromaticity is the isolating factor (Sen et al, 1968; Wallace, 1965). However, without reinforcement or instructions to attend to specific auditory stimuli, the von Restorff phenomenon was present when $\mathrm{dB}$ level was the isolating factor. Thus, in audition, whether a specified tone (Waugh, 1969), another voice (Elmes, Sanders, \& Dove, 1973), or an increase in $\mathrm{dB}$ is used, the von Restorff effect is demonstrable.

Differences in recall performance could not be accounted for by differences in organization as measured by SO or ITR. At no time were either of these measures related to the retardates' performance and were relevant 
to the performance of the young normals only when the SO measure was applied to the control session when it preceded the experimental session. This lends support to Spitz's (1966) contention that normals' SO differs from that of retardates. When the von Restorff condition was presented, the normals' SO also differed from retardates' and suggested a drastic change in strategy.

The retardates' data are not consistent with Leicht and Johnson's (1970) data in that their retardates demonstrated a significant positive relationship between SO and free recall. The most parsimonious explanation of this discrepancy might be the modality of learning: visual (Leicht \& Johnson, 1970) vs auditory. Other findings with retardates have indicated that $\mathrm{SO}$ is related to recall when the stimuli are presented visually (Herriot $\&$ Cox, 1971) but not when presented orally (Sitko, 1970). These studies indicate a relationship between modality and organization in retardates.

The inconsistent findings with retardates and Leicht and Johnson's (1970) observation that increased organization could not account for increased recall in retardates, along with Nelson's (1969) concern for the appropriateness of SO and ITR measures with young normals, suggests the need for additional measures. The measure of CS was introduced to determine the relative use of a strategy based simply on the sequence of incoming stimuli. The salient findings in the CS analyses were that (a) the normals were marginally more consistent than the retardates in their order of recall, (b) CS and recall were related in the normal group, especially with the control list, whereas no such relationship existed with the retardates, (c) the normals' average order of recall differed between conditions, while the retardates' average order was similar in both conditions, and (d) list condition affected the initial recall of normals more than it did retardates.

Apparently, the normals organized the lists differently than the retardates (Spitz, 1966), were relatively more consistent in their order of recall (Winters et al, 1967), changed their strategy of organization with different list conditions (Nelson, 1969), but recalled more even when CS and recall were not related. This latter finding apparently reflects the normals' slightly larger channel capacity, over and beyond their superior use of organizational strategies (Spitz, Goettler, \& Webreck, 1972).

\section{REFERENCES}

Bousfield, A. K., \& Bousfield, W. A. Measurement of clustering and of sequential constancies in repeated free recall. Psychological Reports, 1966, 19, 935-942.

Bousfield, W. A., Puff, C. R., \& Cowan, T. N. The development of constancies in sequential organization during free recall. Journal of Verbal Learning \& Verbal Behavior, 1964, 3, $489-495$.

Deutsch, M. R., \& Sternlicht, M. The role of "surprise" in the von Restorff effect. Journal of General Psychology, 1967, 76, 151-159.

Ellis, N. R. Memory processes in retardates and normals. In N. R.
Ellis (Ed.), International review of research in mental retardation. Vol.4. New York: Academic Press, 1970. Pp. 1-32.

Elmes, D. G., Sanders, L. W., \& Dovel, J. C. Isolation of massedand distributed-practice items. Memory \& Cognition, 1973, 1, 77-79.

Goulet, L. R. Verbal learning and memory research with retardates: An attempt to assess developmental trends. In N. R. Ellis (Ed.), International review of research in mental retardation. Vol. 3. New York: Academic Press, 1968. Pp. 97-134.

Herriot, P., \& Cox, A. M. Subjective organization and clustering in the free recall of intellectually-subnormal children. American Journal of Mental Deficiency, 1971, 75, 702-711.

Jacobs, J. W., \& Foshee, D. P. Use of the von Restorff effect to condition rehearsal in retarded children. American Journal of Mental Deficiency, 1971, 76, 313-318.

Leicht, K. L., \& Johnson, R. P. Effects of rehearsal instructions on recall and organization in free learning of retardates. American Journal of Mental Deficiency, 1970, 75, 163-167.

McManis, D. L. The von Restorff effect in serial learning by normal and retarded subjects. American Journal of Mental Deficiency, 1966, 70, 569-575.

Milgram, N. A. The effects of M.A. and I.Q. on verbal mediation in paired associate learning. Journal of Genetic Psychology, 1968, 113, 129-143.

Nelson, K. J. The organization of free recall by young children. Journal of Experimental Child Psychology, 1969, 8, 284-295.

Sen, A. D., Clarke, A. M., \& Cooper, G. M. The effect of isolating items on serial learning in severely retarded subjects. American Journal of Mental Deficiency, 1968, 72, 851-855.

Shuell, T. J. Clustering and organization in free recall. Psychological Bulletin, 1969, 72, 353-374.

Sitko, M. C. Input organizational strategies of educable mentally retarded and normal boys in free recall verbal learning. Unpublished manuscript, University of Michigan, 1970.

Spitz, H. H. The role of input organization in the learning and memory of mental retardates. In N. R. Ellis (Ed.), International review of research in mental retardation. Vol. 2 . New York: Academic Press, 1966. Pp. 29-56.

Spitz, H. H., Goettler, D. R., \& Webreck, C. A. Effects of two types of redundancy on visual digit span performance of retardates and varying aged normals. Developmental Psychology, 1972, 6, 92-103.

Sternlicht, M., \& Deutsch, M. R. Cognition in the mentally retarded: The von Restorff effect. Journal of Mental Deficiency Research, 1966, 10, 63-68.

Tulving, E. Subjective organization in free recall of "unrelated" words. Psychological Review, 1962, 69, 344-354.

Wallace, W. P. Review of the historical, empirical, and theoretical status of the von Restorff phenomenon. Psychological Bulletin, 1965, 63, 410-424.

Waugh, N. C. Free recall of conspicuous items. Journal of Verbal Learning \& Verbal Behavior, 1969, 8, 448-456.

Winters, J. J., Jr., Gerjuoy, I. R., Crown, D., \& Gorrell, R. Eye movements and verbal reports in tachistoscopic recognition by normals and retardates. Child Development, 1967, 38, 1193-1199.

\section{NOTE}

1. Audiometric measurements were made with a Bruel and Kjaer precision sound-level meter, Type 2203, using a " $C$ " weighting network in the "fast response" mode. This network was selected since it has a flat frequency response $( \pm 2 \mathrm{~dB})$ from $50 \mathrm{~Hz}$ to $5 \mathrm{kHz}$.

(Received for publication August 20, 1973; revision requested September 4,1973 ; accepted October 1, 1973.) 